\title{
Remainders and reminders of the divine. Duns Scotus's critique of images of God
}

Restos y recordatorios de lo divino. La crítica de las imágenes de Dios en Duns Escoto

ANDREW ThOMAS LAZELLA

The University of Scranton

Department of Philosophy

Scranton, PA 18510 (Estados Unidos)

andrew.lazella@scranton.edu

\begin{abstract}
In his Quodlibetal Questions and other texts, John Duns Scotus makes the seemingly-startling claim that angels or wayfarers achieve self-knowledge without recognizing God as their exemplar. I will show how this critique of images follows from Scotus's deeper, more general, rejection of theories of analogy. Despite curtailing the image as a means of understanding God, angels, as well as certain wayfarers, are capable of distinct natural abstractive cognition of God according to Scotus.
\end{abstract}

Keywords: Duns Scotus; intuitive and abstractive cognition; imago Dei; angelic cognition.
Resumen: En sus Cuestiones Quodlibetales y en otros textos, Juan Duns Escoto afirma, de modo aparentemente sorprendente, que los ángeles o los viatores se autoconocen sin reconocer a Dios como su ejemplar. Mostraré cómo esta crítica de las imágenes se deriva del rechazo por parte de Escoto, más profundo y general, de las teorías de la analogía. A pesar de limitar la imagen como un medio para la comprensión de Dios, los ángeles, además de ciertos viatores, son capaces de un conocimiento abstractivo distinto y natural de Dios, según Escoto.

Palabras clave: Duns Escoto, conocimiento intuitivo y abstractivo, imago Dei, conocimiento angélico. 
n his Quodlibetal Questions, John Duns Scotus makes what seems to be a startling claim: "While it may be true that both angel and soul are able to know themselves naturally for the absolute things they are, they cannot know themselves naturally to the extent that they are images of God. In other words, they are not aware that they are images of God"1. As Scotus here states, angels or wayfarers might achieve self-knowledge and yet not recognize God as their exemplar and themselves as its imitation. Despite initial appearances, the concern of this passage and others like it, however, is not whether or not such rational creatures are in fact imagines Dei. Instead, the mimetic agnosia discussed here reflects a deeper, more general, assault on theories of analogy by Scotus.

In what follows, I will show why Scotus rejects images as a viable means of cognizing God. Using angels as a test-case, whose intellectual cognition he believes to be the same as ours in its pure condition, will reveal the hermeneutical inadequacy of images. His critique of images, I will argue, exemplifies a more general principle of his metaphysics: creatures both are and must be considered beings in their own right before they are or can be considered qua their relation of imitation or participation. Although Scotus curtails the image as a means of understanding God, he nevertheless elevates both angelic and human cognition of God to another level. That is, as for an angel, the wayfarer is capable of distinct natural abstractive cognition of God based on intellectual memory. As I will show, this does not threaten the distinction between natural cognition and supernatural beatitude.

1. J. D. Scotus, God and Creatures: The Quodlibetal Questions, trans. Felix Alluntis, Allan B. Wolter (Princeton, Princeton University Press, 1975) q. 14, a. 3, n. 79. Hereafter "Quodlibetal." For references to the Ordinatio and Lectura, see Ioannis Duns Scoti, Opera Omnia (Vatican City, Vatican Polyglot Press, 1950-). For the Reportatio, see Duns Scotus, The Examined Report of the Paris Lecture Reportatio I-A: Latin Text and English Translation, vol. 1 and 2, trans. and ed. Allan B. Wolter, Oleg V. Bychkov (St. Bonaventure, The Franciscan Institute, 2004 and 2008). All translations, with the exception of those from the Quodlibetal and Reportatio, are my own. 


\section{ANGELIC COGNITION, INTELLIGIBLE SPECIES, AND IMAGES}

An image, as Scotus frequently defines it throughout his corpus, is something representing a whole perfectly and by means of imitation $^{2}$. Unlike a mere vestige, perfect representation of a whole means that the image captures its object according to a complete ratio. He explains that when, for example, an animal's whole body is impressed in sand —we might think of a fossil — such a representation of the whole animal qua ratio of animal or insect (and not just one of its bodily parts) provides an image ${ }^{3}$.

An image differs from a mere vestige insofar as the latter represents the whole imperfectly and the part perfectly, and by means of similarity (not imitation). Thus, he states "what is a vestige of the whole is an image of the part." 4 Scotus cites the example of a foot in the sand, whose vestige (i.e., the footprint) represents some fugitive animal, but only imperfectly. The vestigial footprint does not lead one to an immediate cognition of the whole 5 . Without a shared ratio with the animal itself, such a trace warrants us to reason or otherwise infer (sed tantum arguitive) something about the whole, but it does not lead to the immediate cognition of it. On this account, an image surpasses the vestigial trace.

Furthermore, such representation by an image transpires not only by means of similarity, which a vestige achieves; it also must imitate that which it images. Imitation requires a likening of the image to the imaged such that the latter serves as the exemplar and measure of the former. The image inherently references and relates to its exemplar without which it cannot be what it is. For this reason, citing Augustine, Scotus states that two eggs are similar to one another, but the one does not imitate the other. To reach the level of imitation, there must be an order of hierarchy and priority between the two.

2. See, for example, Scotus, Reportatio cit., I-A, d. 3, qq. 3 and 7; Lectura cit., I, d. 3, qq. 2-3; and Ordinatio cit., I, d. 3, qq. 2-3.

3. Ibidem.

4. "[...] quod est vestigium totius est imago partis." SCOTUs, Reportatio cit., I-A, d. 3, q. 3 , n. 76 .

5. See, for example, Scotus, Lectura cit., I, d. 3, p. 2, q. unica, n. 293. 
To understand why Scotus curtails our ability to recognize ourselves as an imago Dei, or image of God, we must look at the means by which a finite intellect can cognize God qua its finite natural condition. Insofar as angels have the same cognitive faculties as us, albeit in an unhampered condition, they provide an idealized test case of what can be known and how. To this end, I follow Scotus in asking: Do angels have actual natural and distinct knowledge (notitia) of the divine essence? ${ }^{6}$ In answering yes to this question, he also shows why such cognition does not transpire through images.

Before answering this question, three terms must be highlighted: natural; distinct; and notitia. With respect to the first, Scotus like most of his medieval peers opposes natural to supernatural knowledge, the latter clearly demarcated as the domain of beatitude. Although he will answer the question in the affirmative, he insists that such distinct knowledge remains natural. To make this case, as we shall see, Scotus will need to employ his famed distinction between intuitive and abstractive cognition.

Second, distinct knowledge can be contrasted to indistinct knowledge, for example, the type of knowledge most often possessed by us in the wayfarer state. We enjoy only indistinct knowledge such that even if we form concepts proper to the divine essence, they are complex concepts incorporating a multiplicity of common simplysimple elements (e.g., ens infinitum). The caveat "most often" should suggest that another, higher, form of knowledge is possible even in the wayfarer state.

And third, notitia - a term for which there is no perfect translation-must be distinguished from knowledge in the sense of scientia. That is, notitia is not discursive reasoning of the kind laboriously undertaken by humans, running hither and thither between terms of the premises and conclusion. Instead, it is a type of simple acquaintance ${ }^{7}$.

6. See "De cognitione angelorum" in ScOTUs, Lectura cit., II, d. 3, p. 2, q. 2 and Ordinatio cit., II, d, 3, p. 2, q. 2.

7. It might be close to what Bertrand Russell calls "knowledge by acquaintance" as opposed to "knowledge by description," to borrow one of Allan Wolter's favorite distinctions. See, for example, A. B. Wolter, Language and Metaphysics, in M. McCord Adams (ed.), The Philosophical Theology of John Duns Scotus (Cornell 
Given the lack of satisfactory single-word English equivalent, I will leave it mostly untranslated in what follows.

To explain how angels cognize God short of supernatural cognition, Scotus identifies two strong contenders: either the angel might possess an intelligible species distinctly representing the divine essence; or it might reflect upon its own essence as an imago Dei (although the latter, as we will see, only yields indistinct notitia). Both Henry of Ghent and Thomas Aquinas reject the former option $^{8}$. If a created intellect could represent the divine essence by means of an intelligible species, they object, then, it seems, beatitude would be awarded to such a creature in this life. A finite intellect would see the divine essence under the aspect of its deity. Although Henry does not offer a satisfactory alternative to intelligible species according to Scotus, Aquinas opts for a natural cognition of the divine essence through itself as an imago Dei.

Scotus faithfully explains Aquinas's argument by recounting the Angelic Doctor's three-fold method of cognition: one whereby we see the thing in itself; another we receive a similitude from the thing itself; and a third we receive a species, not from the thing itself, but from another in which the thing "shines forth" (relucet). As Aquinas himself explains, the first mode can be exemplified by light as seen by the eye, or in the case at hand, cognizing God directly in his essence ${ }^{10}$. Although Aquinas holds that an angel knows itself in this manner, he reserves such direct vision of God for beatitude. According to the second mode, the eye, for example, sees a stone through its image or similitude. Likewise, an angel knows God through itself as an image or similitude of God. Aquinas limits this second mode of cognition to angels insofar as we humans know our soul only through an intermediate species and not immediately

University Press, Ithaca, 1990) 54-67: 57-58. Aquinas defines notitia as what the intellect conceives by cognizing. See SANCTI Thomae Aquinatis, Opera omnia iussu impensaque Leonis XIII P. M. edita, t. 4-5: Pars prima Summae theologiae (Ex Typographia Polyglotta S. C. de Propaganda Fide, Romae, 1888-1889) I, q. 34, a. 1, ad. 2. Hereafter: "ST."

8. Scotus, Lectura cit., II, d. 3, p. 2, q. 2, nn. 270-277 and 280-282.

9. Ibidem, n. 281.

10. AQUINAS, ST cit., I, q. 56, a. 3, resp. 
in its essence ${ }^{11}$. Before delving into this further, we might mention the third mode, such as when we see the person but as reflected in a mirror. For us in our present condition, God is seen as if in a mirror insofar as we must come to know him as he shines forth in vestiges. From his traces found in creation, we reason backwards from such effects to their first cause (e.g., Aquinas's Five Ways).

Unlike embodied intellects, an angel knows God through this middle way of self-reflection for Aquinas because an image of God is impressed upon the angel's very nature ${ }^{12}$. To cognize itself, Aquinas holds, an angel thus must recognize its model. For an image to be an image, it must inherently refer to that which it imitates. In this manner, an angel does not distinctly know the divine essence, but only grasps it indistinctly as its own essence refers to it as its exemplar $^{13}$. Such indistinct cognition, however, requires moving between diverse (and not simply differing) rationes according to a theory of analogy. That is, the angel must move between lower and higher $r a-$ tiones essendi. And here is where imago Dei reasoning goes bankrupt according to Scotus. As will be discussed in the following section, such cognition requires a move between diverse rationes without mediation by a univocal concept of being. Before turning to this argument below, we must observe how Aquinas understands this process to transpire.

Aquinas explains that no created similitude can represent the divine essence distinctly insofar as God's mode of existence (i.e., as subsisting existence itself) radically exceeds all created modes of

11. See, for example, Sancti Thomae Aquinatis, Opera omnia iussu Leonis XIII P. M. edita, t. 22: Quaestiones disputatae de veritate (Editori di San Tommaso, Roma, 1975-1970-1972-1976) vol. 4, q. 10, a. 8, resp. Hereafter "De Veritate."

12. "Cognitio autem qua Angelus per sua naturalia cognoscit Deum, media est inter has duas; et similatur illi cognitioni qua videtur res per speciem ab ea acceptam. Quia enim imago Dei est in ipsa natura Angeli impressa per suam essentiam, Angelus Deum cognoscit, inquantum est similitudo Dei. Non tamen ipsam essentiam Dei videt, quia nulla similitudo creata est sufficiens ad repraesentandam divinam essentiam. Unde magis ista cognitio tenet se cum speculari, quia et ipsa natura angelica est quoddam speculum divinam similitudinem repraesentans." AQUINAS, ST cit., I, q. 56, a. 3, resp.

13. See, for example, AQUinas, $S T$ cit., I, q. 12, a. 4, ad. 1. 
knowing ${ }^{14}$. Anything that exceeds another cannot be comprehended by it because comprehension obtains a distinct and perfect grasp of its object ${ }^{15}$. To virtually comprehend something (as opposed to extensively comprehending something as one body comprehends another), the similitude must share something in common with its represented object, at least on a generic level. For example, a placard depicting dogs and cats might represent all animals. The depicted figures generically share the form of animal in common with them. But a similitude that does not share even a generic ratio in common with its object (e.g., an accident representing a substance) only represents its object analogically. This is because it does not comprehend what is essential to its object, not even on the generic level. Remember, being is not a highest genus.

God's essence as ipsum esse subsistens occupies a higher order qua being than created essences, which must participate in their being. Even on the transcendental level, being is not shared univocally in common between God and creatures. They each possess it according to diverse, but related, rationes ${ }^{16}$. Aquinas concludes from this that a created similitude only represents the divine essence analogically ${ }^{17}$. Even with their pure intellection, angels naturally can know the divine essence only indistinctly insofar as their essences present an imago Dei. In themselves as images, they thus must recognize the primary analogue imitated by their essences. Such analogical cognition is the limit of finite intellects according to Aquinas. Only through the light of glory elevating the intellect to a higher

14. Aquinas, ST cit., I, q. 12, a. 4, resp.

15. Aquinas, De Veritate cit., q. 8, a. 2, resp. Comprehension entails perfect knowledge. See also AQuinas, ST I, q. 12, a. 7, resp.

16. For this common definition of analogy, see, for example, the following from Aquinas: "Analogice dicitur praedicari quod praedicatur de pluribus quorum rationes diuersae sunt sed attribuuntur uni alicui eidem, sicut sanum dicitur de corpore animalis et de urina et de potione, sed non ex toto idem significat in omnibus." AquINAS, Opera Omnia Iussu Leonis XIII P.M. Edita, t. 43: De principiis naturae ad fratrem Sylvestrum. (Roma, Editori di San Tommaso, 1976) VI.

17. "Omnis autem similitudo divinae essentiae in intellectu creato recepta, non potest habere aliquam convenientiam cum essentia divina nisi analogiae tantum." AQUINAS, De Veritate cit., q. 8, a. 1, resp. 
order do any creatures come to see the divine essence distinctly ${ }^{18}$. As we will now discuss, Scotus finds such reasoning faulty due to the general problems he identifies surrounding a mere analogical predication of being.

\section{SCOTUS'S CRITIQUE OF IMAGO DEI}

According to Scotus, an angel cannot reflect upon its essence and recognize itself as an image of God. Using a distinction he derives from Aquinas, he holds that there are two types of images and neither one of them suffices for such notitia ${ }^{19}$. The first type of image represents another and is itself only a means of cognizing (ratio cognoscendi) but not itself cognized, at least not immediately. The second type of image is first cognized as itself something, which once cognized, leads to the cognition of another ${ }^{20}$. An example of the first would be a species in the eye, which only represents something else, but is not itself cognized. An image of the second variety would be, for example, a statue of Hercules. The statue does not lead to cognition of the other except insofar as the object itself is cognized. Unlike a representative species in the eye, leading immediately to that which it represents without directly showing itself, we initially encounter the second type of image as an object in itself, from which we then recognize that it represents such and such object ${ }^{21}$. And this occurs, Scotus tells us, discursively.

But for a theory such as Aquinas's, neither type of image, Scotus argues, can lead to cognition of the divine essence ${ }^{22}$. The general flaw he finds with such a hermeneutics of images lies in its analogical relationality: If we do not already know both absolute terms of the relation, we cannot cognize the relation between

18. Aquinas, De Veritate cit., q. 8, a. 3, resp.

19. See, for example, Aquinas, De Veritate cit., q. 8, a. 5, resp. and ST cit. I, q. 12, a. 9 , resp.

20. Scotus, Lectura cit., II, d. 3, p. 2, q. 2, nn. 283-284.

21. Scotus, Ordinatio cit., II, d. 3, p. 2, q. 2, n. 316.

22. ScotUs, Lectura cit., II, d. 3, p. 2, q. 2, nn. 283-284. 
them ${ }^{23}$. He targets the type of analogical reasoning outlined above, which moves between terms lacking even a generic ratio in common. It is not that Scotus denies that creatures are in fact images of God or that there might be an analogical relationship between God and creatures or between substance and accident ${ }^{24}$. Instead, he denies that the cognition of the one term could lead to cognition of an unknown second term ${ }^{25}$.

Something has the capacity to represent only that which it contains the object's intelligibility either formally or virtually ${ }^{26}$. A placard depicting a dog can represent all animals (or even all living things) because dogs contain the intelligible note of animality. (The drawn image can represent dogs in the first place because of the common shape or form shared between the depiction and actual dogs.) An accident can represent substance or God, according to Scotus, but only qua being and only if they share the concept of being in univocally in common ${ }^{27}$. In this light, we can understand Scotus's response to Aquinas.

The first type of image would require that the angel be a species of the divine essence. This is because images of this kind have the capacity to represent their objects insofar as they share a common form with it. For example, the species in the eye shares a form with the visible object although not its matter. It represents its object because of the shared form. The form of a tree is both in the tree and in the eye, although in the later only formally ${ }^{28}$. In terms of angelic cognition, however, both Henry and Aquinas deny such species, which prompted the question in the first place. As Scotus explains: "Indeed they hold that nothing other than the essence of God is a means of cognizing it just as a similitude is a formal means of representation, since [the divine essence] is infinite." 29 That is,

23. Scotus outlines four ways of knowing: proper; common; adventitious; and relational. ScOTUs, Reportatio cit., I-A, d. 3, q. 1, n. 42.

24. See, for example, Scotus, Quodlibetal cit., q. 14, a. 3, n. 89.

25. Scotus, Quodlibetal cit., q. 14, a. 2, nn. 36-38.

26. See, for example, Scotus, Quodlibetal cit., q. 14, a. 3, n. 78.

27. Scotus, Lectura cit., I, d. 3, p. 1, qq. 1-2, n. 112.

28. SCOTUS, Quodlibetal cit., q. 14, a. 3, n. 78.

29. "Sed angelus non est imago primo modo, quia tunc esset species essentiae divi- 
nothing finite such as an intelligible species can distinctly represent the divine essence because the divine essence is infinite ${ }^{30}$. Thus given Aquinas's own commitments, the first type of images must be ruled out, although as will be discussed in Section 3 below, Scotus will defend the capacity of intelligible species to represent the divine essence under the aspect of its divinity.

With respect to the second type of image, cognition of the thing itself leads us to cognition of that which it imitates. Scotus had this type of image clearly in mind with his claim highlighted in the introduction, namely that angels and humans recognize themselves for the absolute things they are, but do not recognize themselves as images of $\operatorname{God}^{31}$. He responds to a possible counter-argument stating that either the image-relation is identical with the soul's or angel's essence or a necessary consequence of such. Either way, it seems according to the counter-argument, cognition of the essence leads to cognition of the relation. This is because such relations of essential dependence cannot be separated from that on which they depend. If $\mathrm{x}$ essentially depends upon $\mathrm{y}, \mathrm{x}$ cannot be known to be what it is without also knowing $y$. This is the case with an image-relation, such that it is a relation of dependence of the imitation upon the imitated. Cognition of one thus leads to cognition of the other ${ }^{32}$.

Scotus identifies a number of problems with using this second type of image to cognize God. First, cognition of the imagerelation requires knowledge (notitia) of both terms: the imitator as well as the imitated ${ }^{33}$. This being the case, the angel would require a prior cognition of God (i.e., the imitated), which is what must be explained (i.e., how an angel knows God). It does not help to say the image includes the relation of imitation from its very essence as image ${ }^{34}$. For me to recognize the statue of Hercules as a statue of

nae, quam negant: potunt enim nihil aliud ab essentia Dei est ratio cognoscendi ipsam sicut similitudo est ratio formalis repraesentandi, cum sit infinita." SCOTUS, Lectura cit., II, d. 3, p. 2, q. 2, n. 283.

30. See, for example, Aquinas, ST cit., I, q. 12, aa. 2 and 9, resp.

31. Scotus, Quodlibetal cit., q. 14, a. 3, nn. 80 and 82.

32. Ibidem, n. 83.

33. Ibidem, n. 82.

34. Ibidem, n. 83. 
Hercules (or even of some random person), I must already know the imitated term (i.e., Hercules, human being, etc.). This is why Scotus cites Augustine in saying we see the mirror, but we do not see it as a mirror $^{35}$. To use a distinction from Stoicism, such images can be commemorative signs, but not indicative ones ${ }^{36}$. They are reminders of the divine for those who already know God.

Second, as Scotus argues directly against Aquinas, because cognition of one thing leads to cognition of another, such a movement requires discursive reasoning. This is problematic for a number of reasons. First of all, most (including Aquinas) deny that angels reason discursively ${ }^{37}$. Second, and more importantly for our consideration, reasoning from an angel's own essence as image to an indistinct cognition of God as its exemplar presupposes some concept of God to mediate the terms (i.e., image and imaged). As Scotus spelled out earlier in the Ordinatio against those who would reject univocity: "For if God is to be cognized in such a way through a creature, one must prepossess [praehabere] some concept about God, to which we reason, because discursion presupposes some concept of the term to which [termino ad quem]." ${ }^{38}$ Here we see the full weight of Scotus's theory of univocity come to bear upon his critique of images ${ }^{39}$.

All discursion, he maintains, presupposes a simple notion (notitiam) of that to which we discursively reason ${ }^{40}$. As a process "leading to this from this," discursion must presuppose terms between which it moves (i.e., terms to syllogize) ${ }^{41}$. It does not, however, itself yield such simple notions itself. Whether through our abstraction from the sensible data of intuition or through angelic reflection upon intelligible species, the discovery of simple (and simply-simple) terms occurs prior to discursion. If this were not the case, reasoning would

35. Ibidem, n. 79 and Reportatio cit., I-A, d. 3, q. 7, n. 214.

36. G. MANETTI, Theories of the Sign in Classical Antiquity (Bloomington, Indiana University Press, 1993) 100-103.

37. Aquinas, ST cit., I, q. 58, a. 3 and De Veritate cit., q. 8, a. 15.

38. SCOTUs, Ordinatio cit., I, d. 3, p. 1, qq. 1-2, n. 106.

39. He explicates this more clearly in the Ordinatio account than the Lectura one, although it is implicit in the latter.

40. Scotus, Ordinatio cit., II, d. 3, p. 2, q. 2, n. 316.

41. Scotus, Lectura cit., II, d. 3, p. 2, q. 2, n. 284. 
leap to an unknown conclusion without the mediation of the known. Discursion then concludes something about the presupposed simples according to a new composition; it is not itself a discover-platform for unknown elements ${ }^{42}$. We discursively conclude, for example, that "some being is infinite (or first)".

Even if one were to accept Scotus's line of reasoning, however, why should we accept his initial claim that such cognition from images is discursive in the first place? The answer resides in the fact that the same reasoning invoked against analogy holds for images of the second kind. If an angel's essence provides only content representative of finite being, which Aquinas's theory of analogy entails, then an angel neither can abstract simple conceptual notes shared in common with God (let alone simple ones proper to God); nor can it discursively reason to an infinite being due to a lack of a mediation by a middle term. Images must somehow contain their imaged object, or be able to lead us to a cognition of it. The former Scotus subdivides into essential containment (e.g., a species contains the genus) and virtual containment (e.g., a subject contains its attributes). But no created essence, as we will see, contains anything properly representing God (even if indistinctly). What "shines-forth" (relucens) in a phantasm or an intelligible species cannot cause an analogical concept proper to $\mathrm{God}^{43}$. A concept, even stretched to its furthest potential, only represents that with which it shares a common element, even if only transcendentally ${ }^{44}$. For this reason, it cannot represent something with an altogether diverse ratio.

Even if Aquinas were to accept discursive reasoning for an angel, no finite intellect can reason from itself to cognition of God without something to mediate the two orders. All discursion, as we have discussed, presupposes simple notions of that to which it discursively reasons ${ }^{45}$. A prepossessed simple note representing God,

42. See A. B. Wolter, The Transcendentals and Their Function in the Metaphysics of Duns Scotus (St. Bonaventure, NY, The Franciscan Institute, 1946) 40-48.

43. See, for example, Scotus, Lectura cit., I, d. 3, p. 1, qq. 1-2, nn. 26-27.

44. Ibidem.

45. Scotus, Ordinatio cit., II, d. 3, p. 2, q. 2, n. 316. See also Lectura cit., I, d. 3, p. 1, qq. 1-2, n. 27. 
however, must be either shared in common with creatures or proper to God alone. Any conceptual note shared in common between God and creatures would be a univocal concept, which both Aquinas and Henry deny.

The possibility of a concept proper to God alone also can be ruled out for Aquinas and Henry, although not for Scotus as we will discuss in the following section. A created essence cannot contain a conceptual note proper to only God in the absence of God's direct causal influence. Scotus confirms this with a familiar argument used to defend univocity ${ }^{46}$. No object makes a distinct notion of another object unless it contains that other object virtually. He buttresses this claim with an appeal to Metaphysics II.1: status in being determines status in truth. Insofar as an angel does not virtually include God in entity, so too its cognitive content does not virtually contain any note properly representing God.

Virtual containment means having the power (virtus) to produce something else, as an essence produces an attribute or premises produce a conclusion and thereby virtually contain it. This raises a further problem if the angel's essence (as opposed to a representing species) were to contain its exemplar. If the angel's essence were to cognize the divine essence as virtually contained in its own essence (i.e., as exemplar), which seems to be the default option in the absence of common univocal concepts, then the angel intuitively would cognize God in cognizing its own essence ${ }^{47}$. Scotus explains that insofar as the angel intuitively cognizes its own essence, by extension, it intuitively cognizes anything contained therein. An intuitive cognition of the divine essence would be beatitude, which must be rejected.

46. "Confimatur enim, quia nullum obiectum facit distinctam notitiam alterius obiecti nisi includat in se virtualiter illud aliud obiectum, -quia 'unumquodque sicut se habet ad esse, sic ad cognosci'; quod igitur non includit aliquid virtualiter in entitate, non includit illud cognoscibilitate. Sed essentia angeli non includit virtualiter essentiam divinam sub ratione aliqua distincta; ergo nec sic cognosci eam." ScOTUS, Ordinatio cit., II, d. 3, p. 2, q. 2, n. 317.

47. "Si autem non per discursum cognoscat, sed per hoc quod essentia divina includitur in essentia angeli, tunc intuitive cognosceret essentiam divinam, et essentia divina virtualiter contineretur in essentia angeli (quod falsum est)." SCOTUs, Lectura cit., II, d. 3, p. 2, q. 2, n. 284. 
Scotus's theory of univocity can bypass these cognitive dead ends by maintaining the following: True, a proper concept of God requires discursion, leading "hoc ex hoc." 48 Such is the nature of wayfarer scientia, which uses common transcendental concepts to form proper, yet complex conceptions of God. Our intellect leads us from this one to that one account of common content: we presuppose cognition of the terminus ad quem (i.e., God) in the form of common univocal simples abstracted from sensible accidents (e.g., the concept of being). From such simply-simples, we then reason to proper, yet complex, concepts of God (e.g., ens infinitum). Angels, on the other hand, as well as certain humans, distinctly cognize the divine essence under the aspect of divinity through intelligible species proper to God, which we will discuss below.

Aquinas, however, might respond at this point that the angel recognizes God in itself as the image, instead of reasoning to one thing from another ${ }^{49}$. Thus, such images (he would argue) are immune to the requirements of discursive reasoning. They enable the angel to grasp both cause and effect in a single intuitive gaze instead of running hither and thither between extremes. Aquinas cites the example of seeing both a thing and its image at the same time, as when one sees an object and its image simultaneously in a mirror ${ }^{50}$.

But Scotus's critique of analogy from above still stands: namely, how could cognition of God shine-forth, even indistinctly, in conceptual contents derived from creatures, if they do not contain it essentially or virtually? ${ }^{51}$ A creature's essence as image cannot

48. Scotus, Lectura cit., I, d. 3, p. 1, qq. 1-2, n. 27.

49. Aquinas, De Veritate cit., q. 8, a. 15, resp. and ad 6.

50. AQUINAS, $S T$ cit., I, q. 58, a. 3 , ad. 1.

51. "Et confirmatur ratio, quia 'obiectum': praeter conceptum suum proprium adaequatum, et inclusum in ipso altero duorum modorum praedictorum, nihil potest cognosci ex isto obiecto nisi per discursum; sed discursus praesupponit cognitionem istius simplicis ad quod discurritur. Formetur igitur ratio sic, quia nullum obiectum facit conceptum simplicem proprium, in isto intellectu, conceptum simplicem proprium alterius obiecti, nisi contineat illud aliud obiectum essentialiter vel virtualiter; obiectum autem creatum non continet increatum essentialiter vel virtualiter, et hoc sub ea ratione sub qua sibi attribuitur, ut 'posterius essentialiter' attribuitur 'priori essentialiter',-quia contra rationem 'posterioris essentialiter' est includere virtualiter suum prius, et patet quod obiectum creatum 
analogically represent the divine essence, even indistinctly, because such an essence would be of a higher order of being than it. The object and its image simultaneously seen in a mirror both share a univocal form, unlike the angelic image and its analogically superior exemplar.

Before discussing the mechanisms of such angelic cognition further, we must stress that Scotus does not deny that creatures are images of God. Instead, he shows that their discovery as images requires prior knowledge of the related terms ${ }^{52}$. To grasp their imitation of the divine essence, we already must know that which they imitate. (Even if God only rationally relates to creatures, their real asymmetrical mimetic relation requires knowledge of the imitated term.) They are, in effect, reminders of the divine. An angel, or any finite being for that matter, must be understood for the absolute thing that it is prior to understanding its relations of participation or imitation. This is because, Scotus argues, a thing is not a being because it imitates another or participates in its being ${ }^{53}$.

Behind Scotus's critique of images lies a deeper claim concerning the extent to which the relational structures of created beings shines-forth in an understanding of them qua being. That is, can we consider a being qua being (whether ourselves or another) without comprehending its mimetic or participatory constitution? His answer, while subtle, is yes.

He argues that a created being's ratification qua being (ratitudo) lies not in terms of its relation to another ${ }^{54}$. A being is a being, an ens ratum, formally of itself. We do not need to understand the matrix of its causal relations-what it imitates, or how it participates-in order to comprehend its formal constitution as a being (even as a finite or an accidental one!). Only after we have understood the terms

non essentialiter continent increatum secundum aliquid omnino sibi proprium et non commune; ergo non facit conceptum simplicem et proprium enti increato." Scotus, Ordinatio cit., I, d. 3, p. 1, q. 2, n. 35.

52. Scotus, Ordinatio cit., I, d. 3, p. 3, q. 4, n. 575.

53. Scotus, Ordinatio cit., I, d. 3, p. 2, q. unica, n. 326.

54. Scotus, Lectura cit., I, d. 8, p. 1, q. 3, nn. 63-65. 
can we subsequently understand their relations ${ }^{55}$. Thus, despite the fundamental dependency of creatures upon God as that which they imitate, we can understand them for the absolute things that they are without understanding them as images of God.

Remember, the structure of an image requires understanding something's imitation of and reference to another as its exemplar. Scotus thus reduces a creature's asymmetrical relation of imitation to a feature of its being known subsequent to cognition of its ratitudo for the absolute thing that it is ${ }^{56}$. This brings us to the question of how an angel can cognize God without either reflecting upon itself as an imago Dei or discursively reasoning from univocal concepts.

\section{ANGELIC COGNITION OF THE DIVINE ESSENCE}

If an angel naturally knows itself for the absolute thing that it is and yet does not recognize itself as an imago Dei, nor does it engage in wayfarer's demonstrative reasoning from vestiges, then, it seems, angelic knowledge (notitia) falls short of ours. Angels would rely on supernatural cognition of God alone. In response to this issue, Scotus argues against both Henry and Aquinas that a created intellect can achieve natural and distinct notitia of the divine essence ${ }^{57}$. Such cognition, he maintains, results from an intelligible species distinctly representing the divine essence under the aspect of divinity. But this immediately raises the question of how angels obtain such intelligible species if not through abstraction from phantasms. Furthermore, how can such a distinct and natural acquaintance with the divine essence be distinguished from supernatural beatitude?

In terms of this second question, Stephen Dumont has shown perhaps more than anyone else the centrality of Scotus's distinction between abstractive and intuitive cognition in answering this quandary ${ }^{58}$. An angel can have a species distinctly representing the divine

\section{Ibidem.}

56. For further discussion of this matter, see Scotus, Ordinatio cit., I, d. 3, q. 4, n. 326.

57. SCOTUs, Quodlibetal cit., q. 14, a. 3, n. 79.

58. S. D. Dumont, Theology as a Science and Duns Scotus's Distinction between Intuitive and Abstractive Cognition, "Speculum" 64/3 (July 1989) 579-599. 
essence insofar as it does not represent it as existing and present. Such notitia is thus abstractive, not intuitive ${ }^{59}$. It is distinct, however, insofar as it does not require a complex of common concepts assembled to form a proper concept of God, as for example, we do in the wayfarer state ${ }^{60}$. In this manner, Scotus can distinguish such cognition from supernatural beatitude.

This returns us to the first question: namely, how do angels obtain such an intelligible species in the first place? Scotus answers that "most likely" such intelligible species are imparted to their intellect of angels from the beginning (inditam esse intellectui angeli a principio ${ }^{61}$. He explains that such intelligible species, although not following from the nature of the angel itself as an attribute, are nevertheless "natural." It is natural as opposed to supernatural because God gives the perfection to the angel at the time (mora) of its first creation. Unlike supernatural grace and glory, however, such cognition does not require the actual presence of the divine essence as its cause. Although originally imparted by God, such species remains even once the divine essence has withdrawn its immediate causal presence ${ }^{62}$.

The reason why angels continue to enjoy such a divine remainder, whereas we (for the most part) do not, cannot be explained in terms of hierarchical superiority of angelic cognition over ours ${ }^{63}$. Although our current wayfarer condition might suggest otherwise, the human intellect by nature is not limited to the cognition of material quiddities ${ }^{64}$. Scotus rejects this view on the grounds that were our intellect limited in such a way, it would require the formation of an altogether new power in its post-mortem state ${ }^{65}$.

59. Scotus, Ordinatio cit., II, d. 3, p. 2, q. 2, n. 324.

60. SCOTUs, Lectura cit., II, d. 3, p. 2, q. 2, nn. 285-290.

61. Scotus, Ordinatio cit., II, d. 3, p. 2, q. 2, n. 325.

62. Even an angel's "morning cognition" (cognitio matutina), or cognition of creatures as they exist in the divine Word, can be considered natural. ScOTUs, Ordinatio cit., II, d. 3, p. 2, q. 2, n. 329.

63. SCOTUs, Lectura cit., II, d. 1, q. 6, nn. 289-293. Here he argues that angels differ from the soul in terms of species, not however in terms of their intellect or will.

64. Scotus, Lectura cit., I, q. 3, p. 1, qq. 1-2, nn. 35-49. See also Scotus, Reportatio cit., I-A, d. 3, q. 1, nn. 17-22.

65. Scotus, Reportatio cit., I-A, d. 3, q. 1, n. 18. 
He argues as follows: being qua being is the adequate object of our intellect — as seen from wayfarer metaphysics; and nothing prohibits our intellect even in this state from pushing-on to seek satisfaction of its natural desire in a supernatural vision of God; ${ }^{66}$ therefore, divine volition can cause such vision and its subsequent effects without destroying the nature of the human intellect ${ }^{67}$. The cognitive difference between angelic and human cognition results from our current need to abstract from phantasms, due to our intellect's embodied state as opposed to any fundamental intellectual incapacity ${ }^{68}$. (For this reason, as we shall see, the intellect of a postraptured wayfarer is not elevated with a fundamentally new habit, but remains the same power.)

In the case of angels, what they knew in the period before their subsequent beatification or damnation remains (manet ${ }^{69}$. As Scotus explains, angels have not been wounded (vulnerati) in the same way that humans have, and thus they retain a natural habitual cognition of the divine essence ${ }^{70}$. Unwounded, they retain whatever has been given to them at their creation. This means that an angel's memory habitually contains intelligible species, including a species distinctly representing the divine essence ${ }^{71}$. From such species contained in the memory, their intellect can produce a concept, or (as Scotus puts it in more Augustinian terms) express a mental word. The mental word is actual knowledge in the understanding (notitia actualis in in-

66. Scotus, Quodlibetal cit., q. 6, a, 1, n. 22. See A. B. Wolter, The Natural Desire for the Supernatural in M. MCCORD ADAMS (ed.), The Philosophical Theology of John Duns Scotus (Cornell University Press, Ithaca, 1990) 125-147.

67. Scotus, Lectura cit., I, q. 3, p. 1, qq. 1-2, n. 44.

68. ScOTUs, Lectura cit., I, q. 3, p. 1, qq. 1-2 n. 46. For a more extensive discussion of this point, see A. B. WOLTER, The Natural Desire for the Supernatural cit.

69. He distinguishes three times (morae) for an angel: creation, in which there is a uniformity of angels; difformity, in which the good angels act meritoriously and the bad defy God; and an end (terminus), at which the good are confirmed in supernatural beatitude and the bad are damned. ScOTUs, Lectura cit., II, dd. 4-5, qq. $1-2$, n. 33.

70. "Dico tunc ad questionem: quid [angeli] ipsi noverunt in illa mora ante lapsum, Deus novit; sed tamen cognitio naturalis habitualis de Deo adhuc manet, quia non sunt vulnerati in naturalibus, licet in moralibus." ScOTUs, Lectura cit., II, d. 3, p. 2, q. 2, n. 291.

71. SCOTUS, Reportatio cit., I-A, d. 3, q. 5, n. 160. 
telligentia) as generated by the memory ${ }^{72}$. (Under the aspect of being a product, which in the case of created intellects encompasses all knowledge, actual knowledge is coextensive with the word.) Unlike us in our current condition, the angel can immediately speak such a mental word without the mediation of a mental picture ${ }^{73}$. Thus an angel can have a natural cognitive habit of the divine essence because what has been imparted to it from the beginning remains even once the giver has withdrawn its presence. Furthermore, the angel does not need to abstract and construct an indistinct concept of God from vestiges found in the sensible world.

On this basis, Scotus can conclude that angels neither lack natural cognition about God, which had been the concern addressed above; nor is their cognition the confused cognition of the wayfarer from common transcendental concepts. If latter were the true, Scotus argues, they would have no more perfect cognition than I have. We must emphasize Scotus's use of the first person singular pronoun "ego," which distinguishes his own knowledge from the greatest knowledge possible for humans, even in the wayfarer state. Like the angel, the ecstatic (raptus) wayfarer can achieve intuitive cognition of the divine essence, while remaining a wayfarer. Its cognitive power remains unchanged because it is not limited to material quiddities.

To make his case, he cites II Corinthians 12, which recounts Paul's rapturous vision of God. As important as the vision itself is, once the vision has ended, Scotus speculates that Paul's memory records a species of the object seen in a manner comparable to the angel retaining natural and distinct (yet abstractive) cognition of the divine essence ${ }^{74}$. Such an intelligible species retained by the post-ecstatic wayfarer distinctly represents the divine essence ${ }^{75}$. It remains.

Scotus once again emphasizes the abstractive, as opposed to the intuitive, nature of such cognition. Although the cognition

72. Scotus, Reportatio cit., I-A, d. 27, p. 2, q. 1, nn. 110-113.

73. Ibidem, n. 95.

74. Scotus, Lectura cit., II, d. 3, p. 2, q. 2, n. 295. Cf. AQuinas, De Veritate cit., q. 8, a. 5 , ad. 5 .

75. Scotus, Ordinatio cit., II, d. 3, p. 2, q. 2, n. 327. 
originates from a supernatural act caused by divine volition alone (because no created being can cause even an abstractive cognition of God under the aspect of divinity ${ }^{76}$ ), what results and remains is natural cognition. Like the angel, the post-ecstatic wayfarer's cognition is natural insofar as the divine essence shines-forth in the intellect, not on account of its actual presence, but by means of an intelligible species. This caveat distinguishes such cognition from supernatural beatitude. Both angelic and human intellects qua finite intellect can express a mental word distinctly representing the divine essence. Against both Aquinas and Henry, Scotus thus can maintain that angels have distinct and natural notitia of God by means of intelligible species. They can speak a mental word proper to the divine essence as divine without the actual presence of God.

As a final note, we must add that although finite intellects can cognize the divine essence under the aspect of divinity and as a this, they do not naturally cognize its trinity ${ }^{77}$. The latter requires intuitive cognition of the divine essence as existing and present. Unlike the face-to-face encounter of the beatific vision, abstractive cognition represents its object distinctly according to a proxy (i.e., a representing species), but does not include the essence's modes of existence.

This is possible, as Scotus explains, because existence does not add anything to the intensity or clarity of our concept ${ }^{78}$. We might conceive an essence with complete conceptual distinctness and clarity without conceiving that and how it exists. Instead, Scotus tells us, existence indicates how the concept is posited or extended. Existence is but a mode of essences ${ }^{79}$. One thus can distinctly conceive the divine essence according to its transcendental magnitude, and yet

76. Scotus, Quodlibetal cit., q. 14, a. 2, nn. 36-37 and Reportatio cit., I-A, d. 3, q. 1, nn. 41-43.

77. Scotus, Lectura cit., II, d. 3, p. 2, q. 2, n. 307.

78. Scotus, Reportatio cit., I-A, d. 2, p. 1, qq. 1-3, n. 74.

79. Scotus famously denies any real distinction between esse and essentia. He instead opts for a modal distinction between the two. He states: "[...] one can say that the essence and the existence in creatures are like quiddity and its mode. Therefore they are distinct. However, in God existence pertains to the concept of essence and is predicated in the first mode of per se predication, so that the proposition asserting this would be first and immediate, and all other propositions would follow from this, as it appears in I, dist. 2." ScOTUs, Quodlibetal cit. Addition 1.11. 
not cognize its trinity as the Trinity of distinct divine persons. The distinct personal supposita, according to Scotus, do not add to this magnitude. In short, alongside a distinct conception of the divine intellect naturally cognized by means of a representing species, finite intellects do not retain a memory of its modes of existing in supposita.

If a finite intellect can distinctly represent the divine essence according to this infinite magnitude, one might wonder what more does supernatural beatitude offer? As existing and present, the beatific object cannot be more satisfying on account of greater conceptual clarity. Instead, the face-to-face encounter of intuitive cognition satisfies the will insofar as its beloved object stands before it in the flesh as present and existing. Only once the will comes face-to-face with its object can such a supernatural object fully satisfy it. In this respect, Scotus can preserve the distinct natural notitia of angels and certain wayfarers, without demeaning the supernatural excess of intuitive beatific cognition.

\section{CONCLUSION}

In conclusion, we have seen how as part of his general critique of the theory of analogy Scotus curtails the image as a means of understanding God. Neither angels nor humans can simply reflect upon their essence and come to know God as its exemplar. Instead, Scotus argues, wayfarers require a univocal concept of being from which they can construct a proper, yet complex, concept of God. Angels, however, know God through the representing species of abstractive cognition, which they retain "from the beginning." They possess a science of theology with God under the proper aspect of deity (sub propria ratione deitatis) as its subject ${ }^{80}$. Such a propter quid science, which is actual for angels and possible for us in the wayfarer state, may appear to violate the restriction on beatitude short of supernatural access. Despite this elevation of angelic and some human cognition, Scotus nevertheless safeguards the supernatural beatific vision by means of his unique understanding of intuitive cognition.

80. See, for example, Scotus, Reportatio cit., I-A, Prologue. 
